\title{
Obstacles Facing the Iranian Basketball Academy
}

\author{
${ }^{1}$ Hamta Hadian", ${ }^{2}$ Mohamad Reza Boroumand, ${ }^{1}$ Saeed Amirnejad, ${ }^{3}$ Masoud Najafi \\ ${ }^{1}$ Department of Sport Management, Faculty of Sport Sciences, Shomal University, Amol, Iran. ${ }^{2}$ Department of Sport \\ Management, Faculty of Sport Sciences, Shahid Beheshti University, Tehran, Iran. ${ }^{3}$ Department of Sport Sciences, \\ Ayatollah Amoli Science and Research Branch, Islamic Azad University, Amol, Iran.
}

\begin{abstract}
This study, which is a strategic study with a mixed research approach aimed to identify obstacles facing the academies of Iranian Basketball Federation. The population comprises board of directors and committees responsible for Education and Talent Spotting Association, academy administrators, physical education instructors, qualified experts, professors, coaches, referees and heads of delegations who were asked via interviews and questionnaire (exploratory manner) to state internal and external obstacles facing basketball academies in following 8 components in order of importance utilizing the Delphi method: management and planning, training, human resources, financial resources, talent spotting, scientific and research and information technology, venues and infrastructures. Items were identified in 34 external and 49 internal factors. For weighting and prioritizing of items, the questionnaire was completed by 27 subjects employing AHP method based on pairwise comparisons. SPSS software version 18 was utilized for descriptive statistics while AHP method in Expert Choice software was utilized for inferential statistics. At the end, a total of 11 executive strategies were proposed for removing the obstacles.
\end{abstract}

KEY WORDS: Basketball, Academy, Strategic Planning, AHP.

\section{INTRODUCTION}

Evaluating the methods and progress of championship and professional sports in developed countries is indicative of the fact that the elite athletes training approach was focused on the attention and investment in the basic level and development of specialized academies (1). Among the different sport fields, basketball is one of the important, beautiful and popular sports that has a special place in world Championships and Olympics (2). Today, basketball tournaments are held in an amateur way on different occasions at World Championships, Olympics, Student Championships and international tournaments.
In the United States of America, tournaments are held professionally and under special rules as well as the supervision of the American Basketball Association (NBA). In Iran, the basketball federation was first founded by Fereydoun Sharif-zadeh, Alborz high school sport teacher between 1935 and 1936. Moreover, it was developed so fast in Iran that the Iranian national basketball team made its debut at the London Olympics in 1948. Today, basketball tournaments are held in all categories of schools championships, national championships, League Championship clubs and students' championships among men, women, youth,

*. Corresponding Author:

Hamta Hadian

E-mail: hamtahadian82@gmail.com 
adolescents (mini-basketball) (3). The Iranian basketball academies, the number of which is increasing day by day, started functioning officially for the first time by Mahram Co. in 1999 and then by Tehran Etihad Club in 2011. These centers as academic and professional training institutions, seek to discover, train and evolve sport talents. In addition, their significant activities were effective on the professional and scientific development of basketball in light of appropriate sport management and planning. Given the importance of the field in the world, the Iranian basketball more than ever needs more attention for the education, scientific and academic teaching of basketball to coaches and new basketball learners employing modern technology and facilities and organized management measures to promote its position in global arenas. Close competition levels between countries in these events, complexities and specific equations governing these competitions have created special conditions for countries in this process (4). It is reported in results obtained from studies on the comprehensive program of Iran's sport(s) that there is only one coach for every 700 people on average. This ratio is much lower in developed countries. For instance, there is one coach for every 11 and 9 people in America and Canada, respectively. Thus, there is an explicit and institutionalized shortcoming in the number of Iranian coach. A large number of Iranian coaches are not active and only a total of $35 \%$ are actively working. Therefore, the situation is very worrying regarding the number of sports coaches in the country. Furthermore, there are 1062 students per one sport teacher in Iran. The study of this ratio and (also) its comparison with (that of) other countries reveals (a) shortage in number of sports teachers and instructors. For instance, there is one sport teacher for every 28 students in America (5). Training and evolving different age groups require the implementation of a detailed and logical program in all educational dimensions along with the respective components. To strengthen its basic sport and improve sports facilities in primary schools, the UK considered a new budget plan in 2014, a portion of which included aid package worth 30,000 pounds for schools (6). In line with the research, a total of 56 internal obstacles and 39 external obstacles in
7 components were identified in designing the strategy of the Boating and Water Skiing Federation (7). Moreover, the researchers stated the following obstacles in the design and development processes of the comprehensive system of wrestling in Iran: nepotism, better financial incentives in other fields, reduced interest of young people, mass media failure to address the issue, traditional management, scientific and systematic programs and experienced coaches in other countries (8).

The most important internal and external obstacles in the strategic talent spotting program of the Iranian Track and Field Federation were the Managers' and mass media's focus on resultoriented approach and low contribution level of the track and field clubs in nurturing the talents, respectively (9). In a research, carried out on boys football schools in Iran's cosmopolitan city of Tabriz, parents' low awareness of schools' objectives, lack of expertise and work experience of some football school staff were identified as the most important external and internal obstacles (10). In addition, Hamilton Basketball Academy in Australia, defined its strategic objectives based on the following five components in its strategic Plan (2009-20012):

Growth: An increase in the number of participants and devising strategies to keep them;

Marketing and communications: Increasing the awareness level of all committees on the importance and value of all marketing and communications;

Facilities and Places: Creating a place as a home for basketball learners;

Organizational development: Enabling and empowering the academy;

Talent spotting and discovery of brilliant talents: Spotting talents and helping basketball learners achieve the highest level (11).

Moreover, in the strategic program of the Iranian beach volleyball, the most significant internal obstacles were described as follows: lack of human resources, lack of financial resources, lack of articles, lack of adequate land for the beach volleyball, lack of equipment and facilities, lack of attention to volleyball at schools, lack of inter-province competitions. Furthermore, machine life, the rising cost of equipment, lack of adequate funding, lack of advertisements, lack of suitable talent spotting programs, nepotism 
among the board members were said to be among the external obstacles facing Iranian volleyball (12). In a study carried out in Romania titled "management and marketing in basic basketball clubs", the researcher proposed a model for recruitment and training of children at private basketball academies. The results in 12 centers revealed that all of them were planned non-profit organizations, which compete in the competitions organized by the Federation and almost half of them, which were dependent on competitions in different age groups had good productivity in their work (13). Given the importance of academic teaching of basic basketball, the executive of which are basketball academies, obstacles and challenges should be identified in this area by the relevant authorities utilizing a detailed and systematic planning and organization in order to achieve an all-around development in the field of sport in Iran. So, to better realize this goal, attempts were made in this study to identify and prioritize weaknesses and threats facing the educational institution.

\section{MATERIALS AND METHODS}

Since the present study aims to identify the obstacles facing Iranian Basketball Federation academies, the consecutive exploratory mixed method is the best method to carry out the research so that the results can be explained objectively and the actual results can be achieved without any influence or interference.

Participants. The population of this research includes head of the board and committees responsible for education and talent spotting of Iranian Basketball Federation, academy administrators, basic basketball coaches and expert professors. The research sample was purposefully selected from the subjects who were experts and beneficiaries in relation to the research topic. In total, there were 25 and 27 people in the qualitative and quantitative phases of the research, respectively.

Instrumentation. In this study, the following tools were employed to collect the required information: Document analysis, online library search and study of similar projects, investigating programs of some successful countries and relevant organizations in this field and opinion polling beneficiaries, experts and scholars, and conducting purposeful and guided interview. In the qualitative phase, semi-structured and conceptual interviews were utilized. To achieve this, open-ended questionnaires were given to the basketball experts (in an exploratory manner) so that they can include any obstacle in indoor and outdoor settings of basketball academies in the eight components in separate questionnaires based on importance employing the Delphi method. The final questionnaire attained theoretical saturation with 25 experts. The validity of the questionnaires was confirmed according to the experts. AHP method was employed in the quantitative phase, which was carried out with the aim of weighting and ranking factors identified. The questionnaire was designed based on pairwise comparison and was completed by 27 subjects who were selected purposefully. The model inconsistency rate was smaller than $0.1 \%$ in all components, which indicates the acceptable compatibility of the comparisons system.

Data Analysis. SPSS software version 18 was utilized for descriptive statistics while AHP method in Expert Choice software was utilized for inferential statistics.

\section{RESULTS}

Demographic characteristics. A total of 35 and $65 \%$ of the subjects were women and men, respectively. In addition, a total of 35,45 and $20 \%$ of the subjects had master's, doctoral and bachelor's and associate degree, respectively. Furthermore, a total of $85 \%$ of them had degree in physical education and sports management and only $15 \%$ of the subjects who were officials and heads of academies with huge experience in the field of basic basketball had degree other than physical education. Moreover, a total of $95 \%$ of participants had over 11 years of experience in the basketball field.

Analytical findings. A total of 83 items were identified as obstacles in the 8 components _ Management and Planning (table 1), Talent-Finding (table 2), Education (table 3), Financial Resources (table 4), Human Resources (table 5), Equipment (table 6), Scientific and Research (table 7), and Buildings and Infrastructure (table 8)_ for academies of the Iranian Basketball Federation. 
Table 1. weighting of items in component of Management and Planning, In order of preference

\begin{tabular}{|c|c|c|}
\hline Dimension & Items & weight \\
\hline \multirow{7}{*}{ 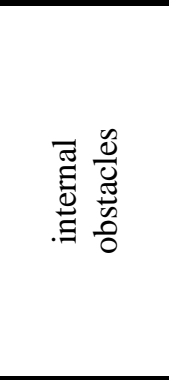 } & lack of developed Articles of Association and by-laws for academies & 0.076 \\
\hline & Lack of clear definition of roles and objectives of academies & 0.039 \\
\hline & The lack of specialized staff and efficient in planning and administration & 0.027 \\
\hline & $\begin{array}{l}\text { Nonconforming of organizational posts of Some staffs in level of education and expertise in } \\
\text { academies. }\end{array}$ & 0.025 \\
\hline & lack of regular monitoring and evaluation system & 0.024 \\
\hline & $\begin{array}{l}\text { Weaknesses in the management structure academies (Most activities are responsible for one } \\
\text { or two person.) }\end{array}$ & 0.016 \\
\hline & Impatient of some of the director of the Academy and their reliance on quick-impact projects & 0.01 \\
\hline \multirow{4}{*}{ 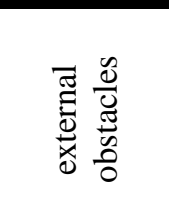 } & $\begin{array}{l}\text { the absence of an independent body called "National Basketball Academy" inside Iran's } \\
\text { Basketball Federation }\end{array}$ & 0.164 \\
\hline & Political managers without sufficient expertise in the field of sport management & 0.071 \\
\hline & The multiplicity of policy and planning in Iran sports & 0.052 \\
\hline & Another claim countries of the integrated system and organized in academies management & 0.022 \\
\hline
\end{tabular}

Table 2. weighting of items in component of Talent-Finding, In order of preference

\begin{tabular}{|c|c|c|}
\hline Dimension & Items & weight \\
\hline \multirow{9}{*}{ 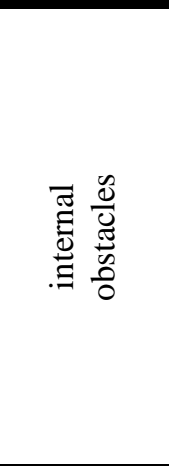 } & Lack of a developed strategic plan for talent finding & 0.135 \\
\hline & $\begin{array}{l}\text { Lack of facilities and equipment suitable for implementation and registration process of } \\
\text { scouting }\end{array}$ & 0.058 \\
\hline & Lack of necessary funds for the process of talent identification and training of talented player & 0.054 \\
\hline & Lack of coordination between the federation and the club's board and in private academies & 0.046 \\
\hline & No regular schedule and rationale for identifying talent in deprived areas & 0.044 \\
\hline & $\begin{array}{l}\text { Weakness appropriate cooperation between talent identification centrall and sport } \\
\text { administration }\end{array}$ & 0.035 \\
\hline & Weakness advertising media from academies to society regarding importance talent finding & 0.033 \\
\hline & Low salaries for coaches talent & 0.028 \\
\hline & Given the talent in certain areas of Iran & 0.028 \\
\hline \multirow{6}{*}{ 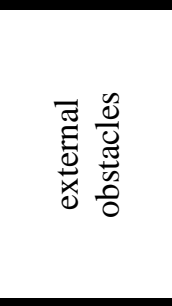 } & Lack of institutionalized plans for talent-hunting in the federation & 0.053 \\
\hline & The private sector's reluctance to invest in talent Basketball & 0.027 \\
\hline & $\begin{array}{l}\text { The focus of the university system to teach students the theory and stay away eyes to apply } \\
\text { scientific findings in the field of talent }\end{array}$ & 0.021 \\
\hline & High costs of transportation, registration and economic weakness livelihoods for some parents & 0.014 \\
\hline & Impose the tendency of parents in orientation activities for children regardless of their talent & 0.012 \\
\hline & Lack of cooperation by some parents of students prone Basketball & 0.008 \\
\hline
\end{tabular}

\section{DISCUSSION AND CONCLUSION}

In the present study, a total of 49 items were identified and weighted in 8 components as internal and external obstacles, among which the absence of a codified statutes and regulations for academics, lack of a strategic program for talent spotting and lack of development path and training model for basketball learners, absence of a written lesson plan based on certain standards, lack of detailed and written financial plan with a separation of all parts, absence of the meritocracy system and good procedure in the recruitment of personnel and coaches in academies, allocation of a meager budget to the academies of Scientific Research and Information Technology, incomplete projects related to basketball venues and infrastructures, lack of equipment for fitness and gymnastics specially designed for basketball, respectively won the highest rating 
and weight in the their components. The absence of a codified statutes and regulations for the academies was recognized as one of the most fundamental weaknesses, for the elimination of which the Basketball Federation, as the competent authority, must form the Strategic Council consisting of athletic directors, coaches and experts in its first step, to fundamentally and systematically formulate the statutes and regulations of the Iranian National Basketball Academy. The implementation of this program will resolve a lot of obstacles and weaknesses. Najafi (2014) stressed the necessity of developing a codified statute for sports academies. Talent spotting program will impose a large financial burden on the shoulders of academics in all parts of the country (14). On the contrary, according to the organization's mission, we should not only focus on certain areas and neglect others. However, costs can be minimized together with advancing the goals and mission of the Academy by utilizing incentive programs to recruit teachers who are volunteer, interested and experienced in this field because they have access to all parts of Iran as well as the target population (children and adolescents). In addition, favorable results will be achieved regarding the elite talents in remote areas. The educational system of each country can have a large share in the development of sports and talent spotting and help grow championship sport (15). According to Daneshjoo News Agency, the missing links in the talent(s) spotting process are sport teachers who can identify and introduce good talents among the students at minimal cost (16).

Table 3. weighting of items in component of Education, In order of preference

\begin{tabular}{|c|c|c|}
\hline Dimension & Items & weight \\
\hline \multirow{7}{*}{ 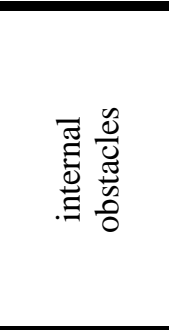 } & absence of a developed syllabus in line with definite standards & 0.074 \\
\hline & Lack of the same class training from the Federation academies & 0.048 \\
\hline & $\begin{array}{l}\text { Lack of coordination Between spending Courses professional Coaching and refereeing } \\
\text { The official documents And stakeholders have }\end{array}$ & 0.04 \\
\hline & Traditionalism some educators in teaching methods & 0.033 \\
\hline & Lack of sufficient attention Academy training system and update educational resources & 0.031 \\
\hline & Lack of physical facilities to the expectations of training academies & 0.03 \\
\hline & Lack of teaching aids (audio-visual) & 0.021 \\
\hline \multirow{6}{*}{ 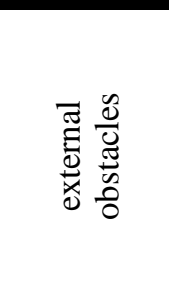 } & low public awareness about educational objectives of basketball academies & 0.054 \\
\hline & lack of specialized workshops such as psychology nutrition and exercise science, etc. & 0.051 \\
\hline & $\begin{array}{l}\text { Lack of attention to teaching basketball in different positions with respect to the } \\
\text { physical and psychological factors, school Basketball }\end{array}$ & 0.029 \\
\hline & Basketball mismatch between the education system with school age academies & 0.026 \\
\hline & Exploitation of the resources of the world's academies competitors & 0.013 \\
\hline & Some parents distrust the educational institution & 0.01 \\
\hline
\end{tabular}

Table 4. weighting of items in component of Financial Resources, In order of preference

\begin{tabular}{|c|c|c|}
\hline Dimension & Items & weight \\
\hline \multirow{4}{*}{ 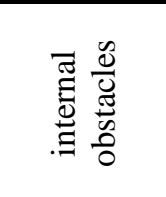 } & no separate clear financial plan for each section & 0.091 \\
\hline & lack of sponsors & 0.043 \\
\hline & The academy's over-reliance on tuition fees and the funding source & 0.037 \\
\hline & $\begin{array}{l}\text { Lack of interest to the academy by its ability to invest in immediate and profitable uses } \\
\text { of cash in the account standing }\end{array}$ & 0.06 \\
\hline \multirow{4}{*}{ 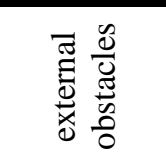 } & lack of supportive laws for financial investors & 0.058 \\
\hline & seasonality nature of some learners in some parts of the country & 0.033 \\
\hline & low share of the academic basketball in the basket of Iranian households & 0.018 \\
\hline & Putting Iran under sanctions economy and the impact on all sections of society & 0.007 \\
\hline
\end{tabular}


Table 5. weighting of items in component of Human Resources, In order of preference

\begin{tabular}{|c|c|c|}
\hline Dimension & Items & weight \\
\hline 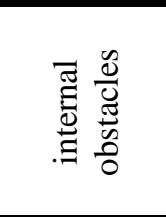 & $\begin{array}{l}\text { lack of a meritocratic system in employment of coaches and personnel of academies } \\
\text { Shortage of personnel trained in different fields of physical education and Basketball } \\
\text { Shortage Human Resources Support (psychology, medicine, nutrition) } \\
\text { Insufficient incentive programs for human resources academies } \\
\text { Shortage Full-time workers working at the Academy }\end{array}$ & \begin{tabular}{c|}
0.117 \\
0.067 \\
0.045 \\
0.028 \\
0.02
\end{tabular} \\
\hline \multirow{2}{*}{ 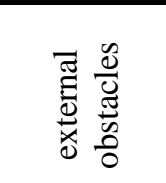 } & $\begin{array}{l}\text { occupations with higher income } \\
\text { Social and cultural restrictions on recruitment of men and women according to the type of } \\
\text { gender-based Academy }\end{array}$ & 0.079 \\
\hline & The presence of emerging powers in the field of human resources academies & 0.029 \\
\hline
\end{tabular}

Table 6. weighting of items in component of Equipment, In order of preference

\begin{tabular}{|c|c|c|}
\hline Dimension & Items & weight \\
\hline \multirow{6}{*}{ 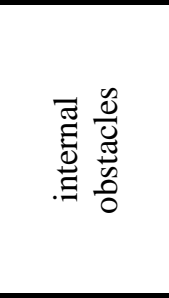 } & Accessories and supplies for basketball talent shortage in Iran & 0.051 \\
\hline & Shortage Modern equipment and teaching aids in accordance with international standards & 0.044 \\
\hline & $\begin{array}{l}\text { inadequate number and distribution of the equipment among basketball learners and coaches in } \\
\text { many academies }\end{array}$ & 0.041 \\
\hline & Amortization of equipment in some of Basketball Academy & 0.041 \\
\hline & lack of equipment for fitness and gymnastics specially designed for basketball & 0.027 \\
\hline & Turmoil in the domestic production of equipment & 0.025 \\
\hline \multirow{4}{*}{ 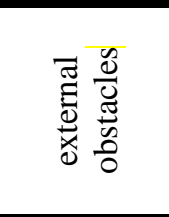 } & in addition to high cost of equipping gymnastics and bodybuilding gyms for academies & 0.078 \\
\hline & The lack of use of new technologies for the production in Iran Basketball Equipment & 0.056 \\
\hline & Poor quality of some imported equipment & 0.027 \\
\hline & $\begin{array}{l}\text { Economic sanctions on Iran for purchasing and importing equipment from countries with style } \\
\text { in basketball }\end{array}$ & 0.021 \\
\hline
\end{tabular}

Table 7. weighting of items in component of Scientific and Research, In order of preference

\begin{tabular}{|c|c|c|}
\hline Dimension & Items & weight \\
\hline \multirow{6}{*}{ 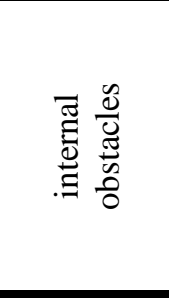 } & insufficient budget allocation for scientific and research and IT departments of academies & 0.073 \\
\hline & Shortage new technologies in academia & 0.064 \\
\hline & $\begin{array}{l}\text { The lack of a comprehensive sites and databases valid for record keeping and documentation } \\
\text { for academics and students active basketball }\end{array}$ & 0.064 \\
\hline & Structural weakness and sometimes substantive informational sites & 0.053 \\
\hline & Relatively low level of staff awareness of (ICT) research and scientific topics & 0.048 \\
\hline & Shortage specificity and lack of attention to research libraries in most academies & 0.038 \\
\hline \multirow{5}{*}{ 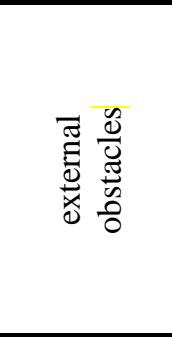 } & $\begin{array}{l}\text { no follow-up measures to realize the proposed plans and focus in all dimensions of basketball } \\
\text { by the relevant authorities }\end{array}$ & 0.094 \\
\hline & $\begin{array}{l}\text { focus of audiovisual broadcast on adult tournaments (ignorance of lower age groups in } \\
\text { basketball) }\end{array}$ & 0.054 \\
\hline & $\begin{array}{l}\text { Lack of scientific and technological information for the development of laws and regulations } \\
\text { in the Iran }\end{array}$ & 0.048 \\
\hline & The use of new technologies in the world's developed countries basketball & 0.027 \\
\hline & The relative enjoyment of the hall and space needed for Basketball & 0.014 \\
\hline
\end{tabular}


Table 8. weighting of items in component of Buildings and Infrastructure, In order of preference

\begin{tabular}{|c|c|c|}
\hline Dimension & Items & weight \\
\hline \multirow{5}{*}{ 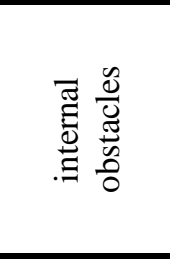 } & incomplete basketball structure and infrastructure projects & 0.067 \\
\hline & Standard open educational space shortage & 0.037 \\
\hline & $\begin{array}{l}\text { Do not use Positioning System (GIS) and due to the topography in the construction of } \\
\text { basketball academy }\end{array}$ & 0.026 \\
\hline & Shortage attention to aesthetic dimension in the halls of basketball & 0.019 \\
\hline & Lack of administrative space for clients Basketball Academy & 0.013 \\
\hline \multirow{2}{*}{ 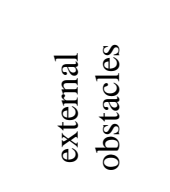 } & $\begin{array}{l}\text { lack of developed plans in other organizations for utilizing the academy resources and } \\
\text { facilities }\end{array}$ & 0.081 \\
\hline & The high cost of land and construction materials in specific areas basketball in urban areas & 0.035 \\
\hline
\end{tabular}

"One of the complaints of academies, coaches and officials during interviews was the fact that they couldn't see the fruits of their efforts after evolving the talented basketball learners and recruitment of the talent strained by the academy or other teams, which imposes high costs on academies in both financial and nonfinancial aspects. The initial contract with basketball learners and receiving fees from them or the commitment to take the possession of the academy during the transfer of the basketball learners to famous teams can be one of the strengths of the academy, which depends on having clear rules and regulations recommended as executive priorities in this regard. In this regard, a similar program was developed for the Volleyball Academy Federation, which emphasized the need for this issue. In addition, lack of regular monitoring and evaluation system for academics and dependence on other government regulatory bodies, which are among other obstacles, can cause many organizational injustices, shortcomings and weaknesses in this area. So, if such system is designed, the academy as an independent body and by enjoying the education in the field will reduce size of the government takeover in various departments and organize the undesirable conditions of some academics and solve the existing weaknesses (14). In addition, in the codification of the strategic plan for the development of volleyball sport, standards and assessment indicators are considered as the main components of the project, which show the importance of the issue (17). Every organization needs to strengthen its financial sector to survive. The academy's over-reliance on tuition fees and the funding source, lack of sponsors, low share of the academic basketball in the basket of Iranian households, seasonality nature of some learners in some parts of the country were among obstacles which can be decreased to an optimal level by accurate and targeted information and advertising and preparing the ground for the positive development of the sector in line with the positive goals of the Academy. The academies can act very positively in this regard by strengthening their marketing potential in attracting the support of government agencies, such as the Ministry of Sport and Youth or other ministries and government agencies as well as the support of private sectors such as companies interested in sports fields. Other innovation of marketers and financial planners related to identification and evaluation of the appropriate investment and profitability platforms for academies can also act as financial supports. Moreover, Goudarzi, Hematinezhad and Keshtidar, insisted on strengthening the sector for the development of sports in the country (17). The efficient and competent manpower is considered as one of the main capital of each organization. So, in order for lack of sufficient supportive forces such as athletic doctors and nutritionists with related educational field(s) not to hinder the 
accomplishment of this important goal, there is need to eliminate the weaknesses in this area by defining a specific framework for recruiting efficient internal and external human resources, utilizing the available opportunities, the most important of which are managers' emphasis on human resources development and employment of domestic and foreign elite coaches as well as educated people with related and necessary subdisciplines. The book titled "Strategic human resource management", while defining the framework, has stressed that the human resources department can offer appropriate programs on issues such as recruitment, planning and implementation of basic training, communication rewards and gaining employee's commitment, in such a way that in a process where change is needed, minimal harm can be imposed on individuals, families and organizations (18). In a study on 22 basketball coaches and 200 professional basketball players in Germany, it was demonstrated that coaches and their leadership capability and competence are very effective on the development of the athletes' performance.

In developing a strategic plan for the Volleyball Federation Academy, Najafi referred to the development of the talent spotting system, determination of statements for assessment and evaluation of academies, preparation of the regulation for the establishment of the academies as well as the approval of license by the Federation and Ministry of Sport and Youth (19). In strategic planning for different parts of Iranian sports, other researchers described the following as the most important internal obstacles facing the sport fields in Iran: lack of meritocracy in the recruitment and appointment of managers, lack of human resources, lack of specified statutes and regulations in many sport institutions, lack of regular monitoring and evaluation system, lack of financial resources, lack of articles, lack of adequate standard space, lack of equipment and facilities, inadequate attention to sports in schools $(7,8,12,17,20)$. Moreover, in this study, external obstacles facing Iranian Basketball Academy were identified and weighted in the form of 34 items in 8 components, which are as follows: absence of an independent institution known as the
National Basketball Academy in the Iranian Basketball Federation, absence of the institutionalized talent spotting program in the Basketball Federation, lack of awareness and public understanding of the educational objectives of the Basketball Academy, absence of specialized commissions such as psychology, nutrition and exercise science ..., lack of laws supporting financial investors, existence of more well-paid jobs, abandoning the pursuit of implementing proposed projects in all aspects of basketball science by relevant authorities, audiovisual media focus on playing the adult tournaments (less attention to basketball at lower age levels), lack of structured programs at other institutions and ministries for academies to use their resources and facilities, high cost of equipping the gym and gymnastics for academies, respectively obtained the highest rating and weight in their components. In this regard, researchers considered increased price of equipment, lack of adequate funding, lack of advertisement and media attention, lack of suitable talent spotting and nepotism as current threats in Iran's sport fields. Others have also proposed the following solutions to remove the current obstacles: the support from sport's highranking managers, taking advantage of young population, utilization of natural spaces, attracting sponsors and promoting sport culture with emphasis on religious teachings in sports, creating talent spotting centers, raising the scientific level of coaches, private sector development and codification of the recruitment and appointment and evaluation regulations ( 7 , $8,12,17,20,21)$. The results demonstrate that weaknesses of sports organizations, including the basketball academies should be more compensated in the aspect of management, planning and implementation. In addition, the threat of financial crisis and lack of attention in updating the resource and achieving a higher level than competitors should be removed by strengthening some factors such as expert sources and more efficient use of existing facilities and opportunities. The findings of this study are consistent in terms of content and context with those of many other similar studies and covered wider items and dimensions in terms of quantity. 


\section{APPLICABLE REMARKS}

- The strategic proposals to eliminate the identified obstacles according to the results of the discussion are:

1. Formation of Iran's organization of National Basketball Academy in the federation structure with the management of expert and relevant persons.

2. Formation of the Strategic Council comprising athletic directors, coaches and experts to fundamentally and systematically formulate principles of the statute and regulation(s) by the National Academy of the Iranian Basketball Federation.

3. Designations of the regular monitoring and evaluation system for academies.

4. Codification of the comprehensive strategic talent spotting plan for the Basketball Federation academies.

5. Establishment of the Department of Education for the promotion and integration of knowledge of coaches and referees.

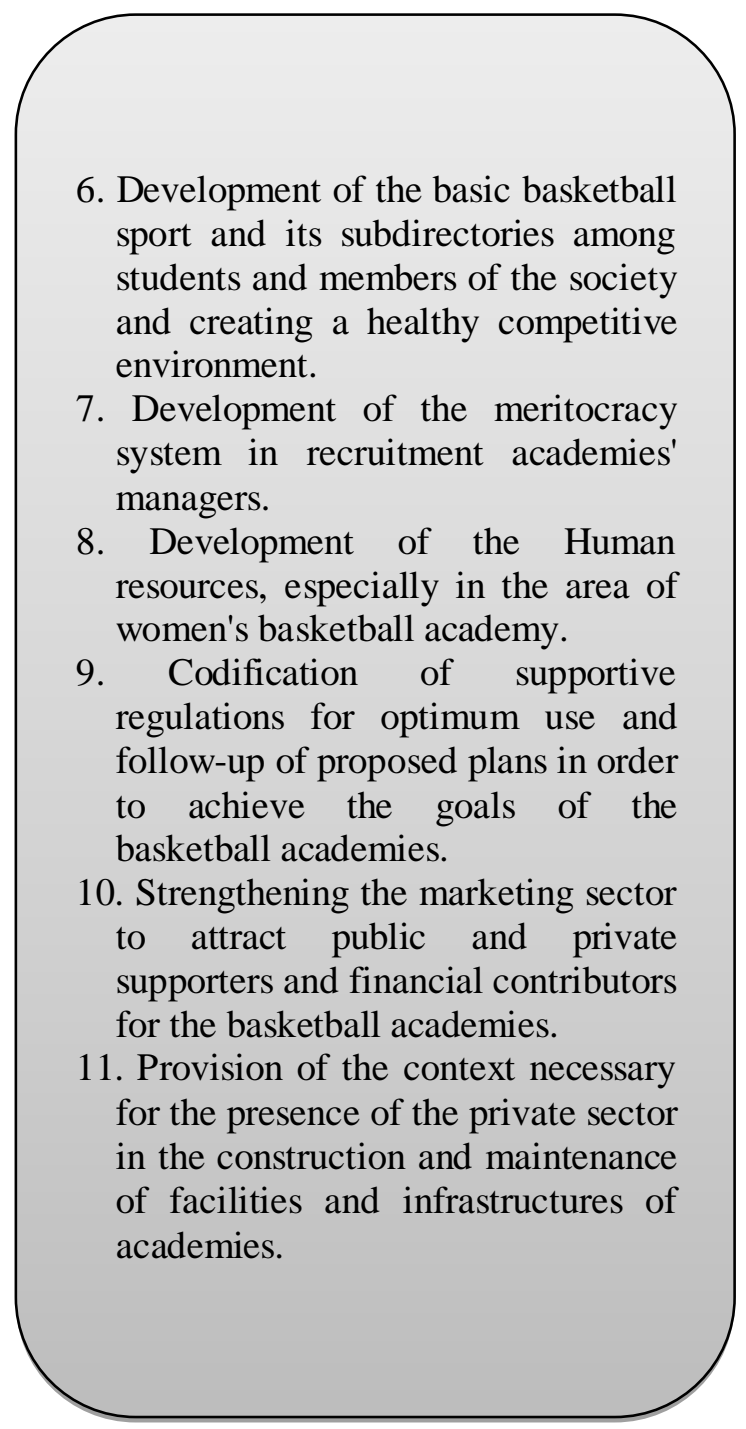

\section{REFERENCES}

1. Asgari B, Ramezani Nezhad R, Ziaei A, editors. The process of discovery and development of talent in selected countries in Europe. 1st National Conference on Sport Talent 2011; Tehran, Iran.

2. Bostani MH, Azarbaijani MA, Kohan pour MA, Mirsepasi M, Bostani MA, editors. The influence of a basketball match On Urinary albumin excretion In competitive basketball players. National Conference on Science and Basketball 2011; Guilan University, Rasht, Iran.

3. Hadavi F. Basketball. 1st ed. Tehran, Iran: Iranian Ministry of Education; 2009 [Book in Farsi]. 188 p.

4. Hadian H. Develop a strategic plan for Academies of Basketball Federation of Iran using a combination method of SWOT and AHP. Amol, Iran: Shomal University; 2014 [Thesis in Farsi].

5. Physical Education Organization of Islamic Republic of Iran. Comparative Studies of Management Development and Planning. 1st ed. Tehran, Iran: Sib-e-Sabz Publishers; 2006 [Book in Farsi]. 280 p.

6. Foster D, Adcock A. School Sport. 2016 Contract No.: SN06836.

7. Hemati Nejad M, Khanzadeh S, editors. Strategic planning and of Water Skiing and Canoe Federation. National Conference on Sport Management: with an emphasis on 20-year-old vision document of the Islamic Republic of Iran; 2008; Tehran, Iran: National Academy of Olympic and Paralympic of Iran.

8. Goudarzi M, Honari H. Designing and Developing the Strategic System of Wrestling in IR Iran Improving Wrestling in Islamic Republic of Iran. World Journal of Sport Sciences. 2009;2(1):65-74. 
9. Ghasemzadeh Mircolaee E. Studying the reasons for the failure and unsustainability of executing Iran's national athletics talent-identification model. Applied Research of Sport Management. 2015;4(14):35-47 [Article in Farsi].

10. Eivazi A. Developing a strategic plan for Tabriz football schools. Sari, Iran: Sari Branch, Islamic Azad University; 2013 [Thesis in Farsi].

11. Hamilton Junior Basketball Association. Strategic Plan 2009-2012 [cited 2016]. Available from: http://websites.sportstg.com/get_file.cgi?id=1090630.

12. Khosravizadeh E, Hamidi M, Yadollahi J, Khabiri M. Iran NOC Strengths, Weaknesses, Opportunities, Threats, Issues and Challenges it confronts. Journal of Sport Management. 2009;1(1):19-35 [Article in Farsi].

13. Grădinaru S. Management and marketing of private basketball clubs for children and juniors. Timisoara Physical Education and Rehabilitation Journal. 2015;7(14):33-6.

14. Najafi M. Developing a strategic plan for academies of Volleyball Federation of Iran. Amol, Iran: Ayatollah Amoli Science and Research Branch, Islamic Azad University; 2014 [Thesis in Farsi].

15. Gazmeh J, Mostafalo A, Ghezelseflo H, Mamshli J, editors. Prioritize barriers sports talent from the perspective of sports teachers and elementary school principals: Case Study State Golestan. 2nd National Conference on Sports Talent; 2012; Tehran, Iran.

16. Student News Agency. Sports teachers, Lost rings in the sport talent 2013 [cited 2016]. Available from: http://www.snn.ir/detail/News/237449/90 [Web Page in Farsi].

17. Kashti Dar M, Talebpour M, Shirmohenji F. The Survey Of Present Statues Of Volleyball In Iran Along With Executive Program For Continuous Improvement. Sport Management Review. 2012;4(13):13-32 [Article in Farsi].

18. Armstrong M. Armstrong's Handbook of Strategic Human Resource Management. 5th ed: Kogan Page Publishers; 2011. $328 \mathrm{p}$.

19. Bormann KC, Rowold J. Transformational Leadership and Followers' Objective Performance Over Time: Insights From German Basketball. Journal of Applied Sport Psychology. 2016;28(3):367-73.

20. Ghasemzadeh Mirkolaee E, Razavi SMH, Amirnejad S. A Mini-Review of Track And Field's TalentIdentification Models in Iran and Some Designated Countries. Annals of Applied Sport Science. 2013;1(3):1728.

21. Najafi M, editor Codifying a Strategic Plan for the Volleyball Academies in Iran for Sections of management and planning, Talent Identification, Education, Based on a Combined Model of SWOT and AHP. 8th International Congress on Sport Sciences, ; 2015; Shahid Beheshti University, Tehran, Iran: Iranian Institute of Sport Sciences Research. 